\title{
Social Services in the Slovak Republic and their Significance for the Roma People
}

\section{A. Gallova (Andrea Gallova)}

St. Elisabeth University of Health and Social Sciences, Bratislava, SK

\section{E-mail address:}

gallova.andrea16@gmail.com

\section{Reprint address:}

Andrea Gallova

St. Elisabeth University of Health and Social Sciences

Nam. 1. Maja 1

81000 Bratislava

SK

Source: Clinical Social Work and Health Intervention

Pages: $20-23$
Volume: 9

Issue: 2

Cited references: 20

\section{Reviewers:}

Tadeusz Bak

Warsaw Management University, PL

Andrea Shahum

Medical University of North Carolina at Chapell Hill, USA

\section{Key words:}

Social Services. Roma ethnicity. Social and economic factors. Senior's homes.

\section{Publisher:}

International Society of Applied Preventive Medicine i-gap

CSWHI 2018; 9(2): 20 - 23; DOI 10.22359/cswhi_9_2_03 (c) 2018 Clinical Social Work and Health Intervention

\section{Abstract:}

Nowadays, Social Services are a significant part of activities and actions performed by public as well as non-public providers of Social Services in Slovakia. The current state of Social Services provisions in Slovakia are based on the legislation frame; social policy of the state; development of the countries in the European Union; societal development of our country. Social Services are usually perceived as services of various subjects focused on social needs of the people who would find themselves in a state of social distress if not provided with such Social Services. 


\section{Introduction}

Currently applicable Law Act No. 448/2008 Coll. on Social Services governs legal relationships within providing Social Services; financing Social Services; supervising provision of Social Services by public and non-public Social Services providers. (Brichtova, Repkova, 2011). Performance of Social Service activities is guaranteed by specialized, operating and other activities. The framework policy of the development of Social Services provisions in the Slovak Republic is based on and takes into account respect for basic human rights, also stated in the Universal Declaration of Human and Civil Rights; and the European Convention for the Protection of Human Rights and Fundamental Freedoms; and developing a common approach to the contents of the European Social Charter pursuant to which disabled people have the right to independence, social integrity and participation in social life; and all other people reliant to help of another natural person, or retired people, as well as individuals, groups or communities being in unfavorable social-economic situation. The government of the Slovak Republic has the goal to integrate the Romani People into the society at all its levels. (Gallova, 2017). In Slovak context there is a high extent of social distance in connection to the Roma People and their low extent of emancipation connected with poverty and negative economic impact on overall quality of their lifes, which are two factors preventing creation of a functional multicultural society. Social Services are based on the matter of Social Services which is a personal relationship arising between providers of Social Services and their recipients. (Brichtova, Repkova, 2012). It is important to motivate citizens in modern and postmodern society to personal involvement in Social Services. Social Services constitute a mechanism, which can improve individual's social skills and widen every single individual's sources of social environment. In the sphere of Social Service it is necessary to direct individual, family or group towards the most important social values. Currently, recipients of Social Services are expected not to be objects receiving Social Services, but they are expected to be subjects participating in organization activities, i.e. to be active recipients of Social Services.

\section{Methods}

Scientific research was performed in Banskobystricky Region: the research file consisted of the facilities for senior citizens; year-long form of stay; public establishments providers; higher territorial unit; town; municipality; non-public providers and the Romani ethnic group citizens living in Banskobystrický Region. The main goal of the research was to find out the significance of Social Services provision to the Romani People and the extent of the interest in Social Services provision to which factors significance is attributed when being or not being interested in placement in the facilities for senior citizens.

\section{Research method: quantitative, qualitative.}

\section{Research instrument: questionnaire, dialogue.}

The examined population and basic examined file consisted of directors and Social Workers in the facilities for senior citizens and the Romani ethnic group citizens in all 13 districts of the region mentioned. We addressed all 61 registered facilities for senior citizens, where there were placed 1,776 clients; our questionnaires were completed by 40 of them; where there were 1,165 clients placed, which meant $65.6 \%$ participation. The age structure of the clients ranged from 
60 years to 100 years. We addressed 300 Romani people to be engaged in our dialogue, out of which 253 participated, which is $84.33 \%$ participation. Within the frame of the research paradigm we set social and socioeconomic factors which we assessed using statistical methods. Our main goal was to find out the significance of services provision to the Romani people through the extent of the interest or disinterest by the help of social and socioeconomic factors. On the basis of the research we wanted either to confirm or contradict Adelfer's ERG Theory. We applied statistical counting methods: Chi-Square test, Wilcoxon test, Spearman's and Pearson's correlation coefficient. The research was based on looking for answers to five essential questions, the main goal being divided into nine partial goals and we determined seven hypotheses.

\section{Result}

On the basis of the results of our research we unambiguously proved validity of the dual theory. The results confirmed the two-factor theses in the part saying that exclusively the social factors are the source of interest in placement into a facility for senior citizens coming from the Romani ethnic group and exclusively socioeconomic factors are the source of not being interested in placement into the facility. We found that substantial problems of thecurrent state of this difficult and responsible Social Work area is a socio-economic factor: segregation, gender, age, human rights, social involvement, integration and having information. Disinterest is shown in the following socioeconomic factors only: social involvement, life style, integration and segregation, having information, work migration, mobility, discrimination, human rights, relations between the Romani and non-Romani citizens, success, participation, political representation, social recognition. As it was proved in the research part of our work, the interest in being placed in a facility for senior citizens is influenced by social factors which are dynamic, and disinterest in being placed in a facility for senior citizens is influenced by socioeconomic factors. Two-factor Theory and socioeconomic factors significantly contributed into knowing and understanding the nature of the Romani People's interest in being placed in a facility for senior citizens. Its main benefit, finding a practical significance within the provision of Social Services, originates from emphasising the fact that the interest in placement in a facility for senior citizens is connected with social factors. We confirmed this fact by means of our research results. Disinterest of a Romani ethnic group senior citizen originating from socioeconomic factors which creates a very strong moment is established in their attitudes, family environment, and conditions supporting them. Expected output and benefit for everyday practical life is measuring and evaluating the degree of interest along with partial factors of interest and also overall interest in being placed in a facility for senior citizens. Through the research we emphasized that the interest in being placed in a facility for senior citizens, as part of overall life comfort of a Romani senior citizen, is significant not only from the view point of their individual experiencing the autumn of life, but undoubtedly it influences also their current mental condition, emotional state, self-confidence, or ability to resist stress and support active entering into difficult situations whereby it consequently influences the quality of life in a facility for senior citizens. At the same time, we came to the result concerning the factors which respondents consider to be most important and that creates an opportunity to implement the measures which would reduce or even remove their disinterest in being placed in a facility for senior citizens. 


\section{Conclusion}

The results of the research: the most important factor supporting the interest is education and similarly the most important role in disinterest originating is played by education. The most powerful negatively diverging factor is segregation. The results of the research are useful either for employees in leading positions in state or public institutions, directors of facilities providing Social Services, and also for supervisors in various areas of their work as well as for the Romani ethnic group.

\section{References}

1. BRICHTOVA L, REPKOVA K (2011) Social protection of older people and persons with disabilities. Bratislava: EPOS, 112 p. ISBN 978-80-8057-909-8.

2. BRICHTOVA L, REPKOVA K (2012) Social protection of older people and persons with disabilities - development since 2012. Bratislava: EPOS, 112 p. ISBN 978-808057-960-9.

3. GALLOVA A (2017) Social Services and their Significance for the Roma People. Rimavska Sobota: ASRPO, 269 p. ISBN 978-80-972352-5-3.

4. Act No. 448/2008 Coll. on Social Services 